ISSN 0130-8521. Передгірне та гірське землеробство і тваринництво. 2021. Вип. 70 (2)

DOI: $10.32636 / 01308521.2021-(70)-2-7$

UDC 620.952

N. L. TKACHUK, Junior Research Fellow

Pre-Carpathian State Agricultural Research Station

of Institute of Agriculture of Carpathian Region of NAAS

S. Bandery street, 21a, Ivano-Frankivsk city, 76015,e-mail: instapv@i.ua

\title{
DYNAMICS OF BIOMETRIC INDICATORS OF ENERGY WILLOW PLANTS DEPENDING ON PLANTING DENSITY AND FEEDING BACKGROUND
}

Development of world civilization is closely linked to energy resources, which significantly affect the country's independency policy.

In the structure of renewable energy sources in the world more than $50 \%$ is energy received from biomass of vegetable origin and $15 \%$ of the total energy used.

Ukraine belongs to energydeficient countries, which is unable to provide the energy sector with fossil fuels, therefore task of alternative energy development for our country is urgent.

In Ukraine, in the last decade, much attention has been paid to improving the efficiency of biofuels and bioenergy, which reduces the dependence of national economy on energy imports, reduce its energy intensity and ensure economic development.

A promising renewable fuel source is the biomass of grass and tree crops. Among wood energy crops, the largest plantations are of willow.

To date, the impact of basic environmental conditions and cultivation technologies on crop productivity has been disclosed in many scientific publications and literary sources. However, currently the issue of the impact of cultivation technology, soil and climatic factors on the growth and development of energy willow plants in the Pre-Carpathians is little studied and insufficiently covered in scientific publications, which causes the relevance of this issue.

The research results showed that the highest shoots $(6.8-7.0 \mathrm{~m}$ on the fifth year of energy willow vegetation) was recorded in the variant with a planting density of 18 thousand pieces/ha. The diameter of the central shoot in this variant was in the range $36-42 \mathrm{~mm}$. Number of shoots $2.1-2.9$ pcs. per 1 plant and $37.8-52.2$ thousand pieces per 1 hectare. The largest diameter of the central shoot was recorded in the variant with a planting density of 12 thousand $\mathrm{pcs} / \mathrm{ha}$, where it was in the range 41$44 \mathrm{~mm}$. Number of shoots $4.2-4.8$ pcs. per 1 plant and 50.4-57.6 thousand pieces per 1 hectare.

After analyzing the dynamics of vegetative mass growth of energy willow, it should be noted that the average increase in one growing year of the five-year cycle ranged from 1.32 to $1.40 \mathrm{~m}$. The annual increase in the diameter of the central shoot was

(C) Tkachuk N. L., 2021 
$7.2-9.2 \mathrm{~mm}$.

Key words: energy willow, vegetative mass, mineral nutrition.

\section{Ткачук Н. Л.}

Прикарпатська державна сільськогосподарська дослідна станція Інституту сільського господарства Карпатського регіону НААН

Динаміка біометричних показників рослин верби енергетичної залежно від густоти насадження і фону живлення

Розвиток світової цивілізації тісно пов'язаний 3 енергетичними ресурсами, що суттєво впливають на незалежну політику країни.

У структурі відновлюваних джерел енергії у світі більше 50 \% займає енергія, отримана з біомаси рослинного походження, та $15 \%$ всієї сукупної енергії, яка використовується.

Україна належить до енергодефіцитних країн, яка не в змозі забезпечити енергетичну галузь викопними видами палива, тому для нашої держави $є$ актуальним завдання розвитку альтернативної енергетики.

В Україні в останнє десятиріччя значну увагу приділяють підвищенню ефективності використання біопалива та біоенергії, що дозволяє зменшити залежність національної економіки від імпорту енергоносіїв, знизити іiі енергоємність і забезпечити економічний розвиток.

Перспективним поновлюваним джерелом палива $\epsilon$ біомаса трав'янистих i деревних культур. Серед деревних енергетичних культур вирощують найбільші плантації верби.

На сьогодні вплив основних умов середовища та технологій вирощування на продуктивність сільськогосподарських культур розкрито в багатьох наукових виданнях і літературних джерелах. Проте на теперішній час питання щодо впливу технології вирощування та грунтово-кліматичних чинників на ріст і розвиток рослин енергетичної верби в умовах Передкарпаття мало вивчено і недостатньо висвітлено в наукових публікаціях, що обумовлює актуальність цього питання.

Результатами досліджень встановлено, що найбільшу висоту пагонів за п'ятий рік вегетації верби енергетичної зафіксовано у варіанті з густотою садіння 18 тис. шт./га (6,8-7,0 м). Діаметр центрального пагона за цього варіанта був у межах від 36 до 42 мм, кількість пагонів - 2,1-2,9 шт. на 1 рослині та 37,8-52,2 тис. шт. на 1 гектарі. Найбільший діаметр центрального пагона зафіксовано за варіанта з густотою садіння 12 тис. шт. /га, де він був у межах від 41 до 44 мм, кількість пагонів - 4,2-4,8 шт. на 1 рослині та 50,457,6 тис. шт. на 1 гектарі.

Проаналізувавши динаміку наростання вегетативної маси верби енергетичної, слід відзначити, що середній приріст за один вегетаційний рік п’ятирічного циклу становив від 1,32 до 1,40 м, річний приріст за діаметром центрального пагона - 7,2-9,2 мм.

Ключові слова: верба енергетична, вегетативна маса, мінеральне живлення. 
Introduction. Since the beginning of the new century, humanity is actively seeking to replace traditional energy sources with renewable energy sources. This need is largely due to the depletion of world hydrocarbon reserves, disruption of the natural balance of ecosystems, global environmental problems, including increasing greenhouse gas concentrations in the atmosphere, leading to frequent natural disasters and drastic changes in the earth's surface. Therefore, the development of such a new branch of science as bioenergy is becoming increasingly important, which can become an important element in reducing the deficit of fossil hydrocarbons and the basis for sustainable provision of the state with bioresources and energy security.

In Ukraine, in the last decade, much attention has been paid to improving the efficiency of biofuels and bioenergy, which reduces the dependence of the national economy on energy imports, reduce its energy intensity and ensure economic development $[5,7,11,12]$.

One of the main factors of balanced ecological and economic development of Ukraine is the efficient use of natural resources, in particular, renewable energy sources in the balance of the country's agroindustrial and forestry complex. It is known that European countries have achieved $10 \%$ of their energy needs through renewable energy [9, 30]. In Ukraine, this figure is only 4\%, but Ukraine's energy strategy for the period up to 2030 obliges to increase the share of renewable energy sources to $10 \%$ [29-30]. Our state is forced to import about 65\% of energy. The vast majority of imports are natural gas (79\%) and petroleum products (66\%), the price of which is constantly rising.

At the same time, Ukraine's potential in terms of renewable energy production is quite large. First of all, this is due to the fact that Ukraine has a scarce resource in the world - land. We have a large number of arable lands, which, for one reason or another, are not used in agricultural production and which would be quite suitable for growing bioenergy crops. Thus, there are all the prerequisites for the creation of a national bioenergy complex. Moreover, the global growth in demand for energy crops contributes to rising prices for bioenergy raw materials, which, in turn, generates growth in supply. Therefore, agriculture in Ukraine has every chance to become an industry that can provide not only food but also, to some extent, energy security of the country [15].

However, in the energy balance of Ukraine the share of renewable energy sources remains insignificant $2.7 \%$, of which $1.9 \%$ is hydropower and only $0.8 \%$ biofuels, wind and solar energy. Thus, a large reserve for 
increasing the percentage of biofuels in the energy balance of Ukraine may be biofuels derived from the cultivation of energy crops.

The dependence of Ukraine's economy on energy imports necessitates the search for alternative sources to obtain them. The solution to this problem in the near future is extremely important. Especially given that in 7-10 years the world's proven oil reserves will be depleted by 60 $65 \%$, natural gas reserves will be enough only for 50-60 years, oil - for 25-30, coal - for 500-600 years. Constantly rising tariffs for gas and utilities further stimulate the search for, introduction and use of alternative, non-traditional energy sources.

Increasing energy consumption, while increasing the price of energy resources and increasing harmful emissions into the atmosphere, makes the development of bioenergy extremely important.

Much attention is paid to the use of biomass as a source for biofuel production in Germany, Poland, Sweden and Denmark.

Among the promising crops for green energy are such major energy crops as energy willow [22, 23], poplar [24, 25], miscanthus, candlegrass, perennial sedge. These crops are undemanding to soil and climatic conditions, due to many years of continuous cultivation improve soil structure, and fallen leaves and root residues that remain in the soil can somewhat improve its fertility.

Energy willow is the main energy crop for solid fuel production in the world. This is a plant with a very high weight gain (14 times larger than a naturally growing forest). The average annual increase in yield per hectare is 15-30 tons of wood. Harvesting is carried out every 2-3 years [10].

Energy willow is a species of willow (Salix) that grows quickly and is suitable for use as biomass. It is used by direct combustion of shredded biomass or for the production of fuel pellets and reduces the loss of traditional energy sources. Among all energy plants in the world, willow is today used as the main energy crop for the production of solid fuels [13, 20, 22]. The largest willow plantations today in Sweden, which are about 18-20 thousand hectares, in neighboring Poland more than 6,000 hectares. In Ukraine, despite the large number of unused non-agricultural lands, industrial plantations of energy crops are still insufficient. The average weight gain of energy willow is 1.5 meters per year. Harvesting takes place every 2-3 years, the harvest period is November - February, when the leaves fall. The number of harvest cycles from one planting is 7-8 times, after which it is possible to recultivate the land for planting other crops or establish a new willow plantation. Today willow is effectively used in antierosion measures to strengthen soils; enriches soils with minerals and trace 
elements, nutrients of natural origin; energy willow plantations are natural filters for the removal of agricultural waste, used as buffer zones in places of accumulation of biological waste from farms; energy willow is a natural filter for cleaning soils from pesticides [27]. Willows can withstand periodic water cover, but are not a water crop. Thus, willow survives in meadows and areas with periodic flooding, where the cultivation of conventional crops is for some reason risky [28]. Another advantage of growing this crop is that compared to traditional crops, energy willow plantations require 3-5 times less nutrients and replenish organic matter in the soil due to leaf fall. They cover much deeper soil horizons than, for example, cereals, receiving additional nutrients and moisture from them. Created energy plantations significantly improve the aesthetic and ecological condition of agricultural and urban landscapes, increase the diversity of flora and fauna $[8,26]$. Willow plantations are widely used to secure river banks and ravines, and due to their high transpiration capacity (intensive evaporation of moisture from the leaf blade surface) are used to drain soils [4, 16, 17]. A number of studies have been conducted and the positive aspects of the use of energy crops have been proven $[1,2,4,17,18]$. However, there are many reasons that motivate scientists to look for new, alternative energy sources, and one of them is ecology. Most "energy" plants form a powerful vegetative mass that intensively photosynthesizes, reducing excess carbon dioxide in the atmosphere and the effects of the "greenhouse effect" of anthropogenic origin. The root system, with long-term cultivation in one place, enriches the organic matter content in the soil thereby increasing its fertility $[14,18$, 20, 24].

Materials and methods. Research was carried out in the research fields of the Carpathian State Agricultural Research Station of the Institute of Agriculture of the Carpathian region of NAAS and in the laboratory [3].

The soil of the experimental field is sod podzolic. The thickness of the humus horizon is $40 \mathrm{~cm}$. The granulometric composition of the soil is coarse-medium-loamy. The structure of the arable layer is sprayed (lumpydusty). Therefore, after the rains, these soils can float and form a crust. Agrochemical characteristics: $\mathrm{pH}_{\text {salt }}$ (potentiometric) - 4.6, the amount of absorbed bases $(\mathrm{Ca}+\mathrm{Mg})-11.4 \mathrm{mg}$-eq/100 g (according to Kappen), humus content (according to Turin) $-2.54 \%$, alkaline hydrolyzed nitrogen (according to Cornfield) - 79.0, mobile phosphorus (according to Kirsanov) - 48.0, mobile potassium (according to Kirsanov) - $82.0 \mathrm{mg} / \mathrm{kg}$ of soil; mobile forms of microelements: boron (according to Berger and Truog) 1.0 , molybdenum (according to Grieg) -0.20 , manganese (according to Peive and Rinkis) $-48.0 \mathrm{mg} / \mathrm{kg}$ of soil. 
The research involves the study of the influence of a number of factors (planting density, mineral nutrition) on the growth, development and productivity of crops.

\section{The scheme of the experiment}

\begin{tabular}{|c|c|c|c|}
\hline Culture & \multicolumn{2}{|c|}{ Planting density } & Mineral nutrition \\
\hline \multirow{6}{*}{ Energy willow } & 1 & \multirow{2}{*}{$\begin{array}{l}18 \text { thousand } \\
\text { pcs/ha }\end{array}$} & Without fertilizers \\
\hline & 2 & & $\mathrm{~N}_{40} \mathrm{P}_{300} \mathrm{~K}_{300}+\mathrm{N}_{40}$ \\
\hline & 3 & \multirow{2}{*}{$\begin{array}{l}15 \text { thousand } \\
\mathrm{pcs} / \mathrm{ha}\end{array}$} & Without fertilizers \\
\hline & 4 & & $\mathrm{~N}_{40} \mathrm{P}_{300} \mathrm{~K}_{300}+\mathrm{N}_{40}$ \\
\hline & 5 & \multirow{2}{*}{$\begin{array}{l}12 \text { thousand } \\
\mathrm{pcs} / \mathrm{ha}\end{array}$} & Without fertilizers \\
\hline & 6 & & $\mathrm{~N}_{40} \mathrm{P}_{300} \mathrm{~K}_{300}+\mathrm{N}_{40}$ \\
\hline
\end{tabular}

The experiment is based on four repetitions. The sown area is 150 $\mathrm{m}^{2}$, the accounting area is $125 \mathrm{~m}^{2}$. The total area of the plots in the experiment is 0.36 ha.

According to the planting scheme, the crops are planted in paired rows with a distance of $0.70 \mathrm{~m}$ and row spacing of $2 \mathrm{~m}$.

Results and discussion. Soil preparation consisted of the following technological operations: stubble peeling, plowing and preplanting tillage. In order to prune rhizomes, destroy wheatgrass and other root-sprouting weeds, peeling was carried out to a depth of $16 \mathrm{~cm}$ with a BDT-3 disc harrow in a unit with a $\mathrm{T}-150 \mathrm{~K}$ tractor. The next technological operation was plowing the soil to a depth of $22 \mathrm{~cm}$.

Two weeks after plowing, the soil was loosened and leveled to a depth of $12 \mathrm{~cm}$ with a cultivator KPSP-4 with toothed harrows. This allowed to destroy the sprouted weeds and level the surface of the field. Prior to this operation, according to the scheme of the experiment, fertilizers were applied to the planned areas in the norm of $\mathrm{N}_{40} \mathrm{P}_{300} \mathrm{~K}_{300}$. The following mineral fertilizers were used for research: nitrogen - in the form of ammonium nitrate $(34.4 \%$ d. r.); potassium - potassium chloride $(60 \%$ d. r.); phosphorus - granular superphosphate $(18.7 \%$ d. r.). Fertilizers were applied to the plots in the spring by manual cultivation. Cuttings $22-25 \mathrm{~cm}$ long and $0.8-1.00 \mathrm{~cm}$ in diameter were used for planting. 5-12 buds on each cutting. During planting, the buds were dormant and swollen. The distance between the buds was from $2 \mathrm{~cm}$ to $5 \mathrm{~cm}$.

Before planting, the cuttings were soaked in water for 24 hours. 12 days after planting, the soil was loosened and weeds were destroyed in between rows of willows by a cultivator. 
As of 12.05 , the height of willow shoots ranged from $6.2 \mathrm{~m}$ to 6.5 $\mathrm{m}$. The diameter of the central shoot for this period ranged from 30 to 41 $\mathrm{mm}$. Number of shoots $2.1-4.8 \mathrm{pcs}$. The largest increase in vegetative mass according to the conducted phenological studies was obtained for the period from June to August. The last biometric measurements were carried out on 08.10. The height of plants in this period was in the range of $6.5-7.0 \mathrm{~m}$. The diameter of the central shoot was in the range of 36 to $44 \mathrm{~mm}$. The number of shoots did not change (Table 2).

2. Biometric indicators of energy willow plants depending on planting density and feeding background

\begin{tabular}{|c|c|c|c|c|c|c|c|c|c|}
\hline \multirow{4}{*}{ 总 } & \multicolumn{6}{|c|}{ Date of accounting } & \multirow{2}{*}{\multicolumn{3}{|c|}{$\begin{array}{c}\text { Average increase for } \\
\text { one growing year }\end{array}$}} \\
\hline & \multicolumn{2}{|c|}{26.05 .2016} & \multicolumn{4}{|c|}{08.10 .2020} & & & \\
\hline & \multirow[b]{2}{*}{ 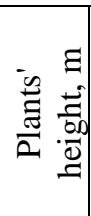 } & \multirow[b]{2}{*}{ 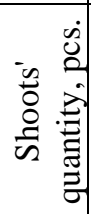 } & \multirow[b]{2}{*}{ 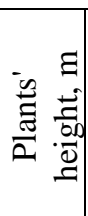 } & \multirow{2}{*}{ 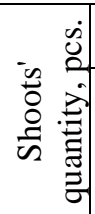 } & \multicolumn{2}{|c|}{ Diameter, mm } & \multirow[b]{2}{*}{ 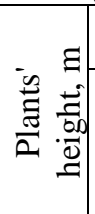 } & \multicolumn{2}{|c|}{ Diameter, $\mathrm{mm}$} \\
\hline & & & & & $\begin{array}{c}\text { on } \\
0 \mathrm{~cm}\end{array}$ & $\begin{array}{l}\text { on } 1 / 2 \\
\text { height }\end{array}$ & & $\begin{array}{c}\text { on } \\
0 \mathrm{~cm}\end{array}$ & $\begin{array}{l}\text { on } 1 / 2 \\
\text { height }\end{array}$ \\
\hline 1 & 0,25 & 0,1 & 6,8 & 2,1 & 36 & 25 & 1,36 & 7,2 & 5,0 \\
\hline 2 & 0,28 & 2,0 & 7,0 & 2,9 & 42 & 29 & 1,40 & 8, & 5,8 \\
\hline 3 & 0,34 & 1,8 & 6,6 & 2,4 & 38 & 26 & 1,32 & 7, & 5,2 \\
\hline 4 & 0,36 & 2,7 & 7,0 & 3,6 & 46 & 32 & 1,40 & 9 & 6,4 \\
\hline 5 & 0,56 & 2,6 & 6,5 & 4,2 & 41 & 27 & 1,30 & 8,2 & 5,4 \\
\hline 6 & 0,55 & 3,0 & 6,8 & 4,8 & 44 & 35 & 1,36 & 8,8 & 7,0 \\
\hline
\end{tabular}

The highest shoots in the fifth year of vegetation was recorded in the variant with a planting density of 18 thousand pieces/ha $-6.8-7.0 \mathrm{~m}$. The diameter of the central shoot in this variant ranged from 36 to $42 \mathrm{~mm}$. Number of shoots $2.1-2.9$ pcs. per 1 plant and 37.8-52.2 thousand pieces per 1 hectare. The largest diameter of the central shoot was recorded in the variant with a planting density of 12 thousand pieces/ha, where it was in the range from 41 to $44 \mathrm{~mm}$. Number of shoots $4.2-4.8$ pcs. per 1 plant and 50.4-57.6 thousand pieces per 1 hectare.

The application of mineral fertilizers $\left(\mathrm{N}_{80} \mathrm{P}_{300} \mathrm{~K}_{300}\right)$ provided the plants with more available nutrients and helped to increase the thickness of the shoots from 3 to $8 \mathrm{~mm}$. The height of the plants was $0.2-0.4 \mathrm{~m}$ higher than in the variant without fertilizers.

Analyzing the increase in biometric indicators of energy willow in the fifth year of the growing season, it should be noted that they were 
significantly lower than in the third and fourth growing seasons. Thus, in the third year of vegetation the height of plants increased by an average of $1.8 \mathrm{~m}$, in the fourth year of vegetation the increase was on average $0.8 \mathrm{~m}$, and in the fifth vegetation year only $0.5 \mathrm{~m}$. This also applies to the diameter of shoots, where in the third year of the growing season the diameter of the central shoot increased by an average of $14 \mathrm{~mm}$, in the fourth year of the growing season the increase was on average $3 \mathrm{~mm}$, and in the fifth growing year only $2 \mathrm{~mm}$.

Analyzing the dynamics of growth of vegetative mass of energy willow, it should be noted that the average increase in one vegetative year of the five-year cycle ranged from 1.32 to $1.40 \mathrm{~m}$. The annual increase in diameter of the central shoot was 7.2-9.2 $\mathrm{mm}$.

After the first three-year cycle of vegetation, part of the shoots of energy willow was cut. During the phenological observation of the growing shoots of the second year, the following biometric indicators were obtained: plant height $302.2-401.0 \mathrm{~cm}$, diameter of the central shoot 9-16 mm. The number of shoots increased significantly compared to the first cycle of vegetation and was 9-12 pieces on the plant (Table 3).

\section{Biometric indicators of two-year energy willow plantations after cutting the first three-year cycle}

\begin{tabular}{|c|c|c|c|c|c|c|c|c|}
\hline \multirow[b]{3}{*}{ 总 } & \multicolumn{6}{|c|}{ Date of accounting } & \multirow{2}{*}{\multicolumn{2}{|c|}{ Increment }} \\
\hline & \multicolumn{3}{|c|}{$10.05 .2020 \mathrm{p}$} & \multicolumn{3}{|c|}{$08.10 .2020 \mathrm{p}$} & & \\
\hline & 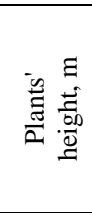 & 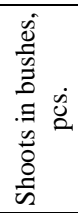 & 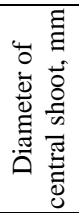 & 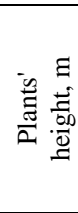 & 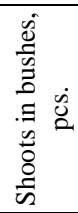 & 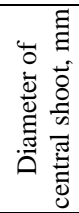 & 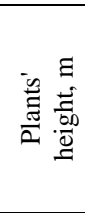 & 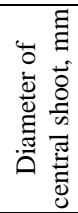 \\
\hline 1 & 1,28 & 8 & 4 & 3,02 & 9 & 9 & 1,74 & 5 \\
\hline 2 & 1,54 & 11 & 7 & 3,23 & 11 & 12 & 1,69 & 5 \\
\hline 3 & 1,34 & 9 & 6 & 3,30 & 9 & 11 & 1,96 & 5 \\
\hline 4 & 1,56 & 8 & 7 & 3,49 & 9 & 12 & 1,93 & 5 \\
\hline 5 & 1,63 & 8 & 9 & 3,65 & 10 & 14 & 2,02 & 5 \\
\hline 6 & 1,80 & 12 & 11 & 4,01 & 12 & 16 & 2,21 & 5 \\
\hline
\end{tabular}

Conclusions. The results of research have shown that increasing the area of nutrition and application of mineral fertilizers promotes better growth and development of energy willow. The application of mineral fertilizers $\left(\mathrm{N}_{80} \mathrm{P}_{300} \mathrm{~K}_{300}\right)$ provided the plants with more available nutrients 
and helped to increase the height of the plants and the thickness of the shoots during the growing season.

\section{Список використаної літератури}

1. Біоенергетичні культури для виробництва біопалива / М. В. Роїк та ін. Вісник Полтавської державної аграрної академії. 2010. № 7: Енергозбереження та альтернативні джерела енергії: проблеми і шляхи їх вирішення. С. 12-17.

2. Гнап I. В. Вплив азотних добрив на ріст, продуктивність і якість біомаси деяких сортів енергетичної верби в умовах Західного Полісся України. Наукові доповіді Національного університету біоресурсів $\quad$ п природокористування України. 2018. № 5. URL: http://journals.nubip.edu.ua/index.php/Dopovi di/article/view/11664/10113 (дата звернення: 04.08.2021).

3. Доспехов Б. А. Методика полевого опыта (с основами статистической обработки результатов исследований). Изд. 5-е, доп. и перераб. Москва, 1985. 351 c.

4. Економічна та енергетична ефективність вирощування біоенергетичних культур в умовах західного регіону / М. Д. Волощук та ін. Передгірне та гірське землеробство $i$ тваринництво. 2020 . Вип. 68 (1). С. 35-51.

5. Кравчук В. На шляху до створення плантацій енергетичних культур. Техніка $i$ технології АПК. 2013. № 2. С. 31-34.

6. Лис Н. М., Фучило Я. Д., Ткачук Н. Л. Вплив густоти і внесення мінеральних добрив на ріст і продуктивність плантацій енергетичної верби в умовах Прикарпаття. Біоенергетика. 2018. № 2 (12). С. 19-21.

7. Макарченко В. Енергетичні культури в Україні. Київ, 2012. С. 114-117. (Agroexpert: практичний посібник аграрія).

8. Методологія дослідження енергетичних плантацій верб і тополь / Я. Д. Фучило та ін. Київ, 2018. 137 с.

9. Роїк М. В. Перспективи вирощування енергетичної верби для виробництва біопалива. Збірник наукових

\section{References}

1. Bioenergy crops for biofuel production / M. V. Roik et al. Visnyk Poltavskoi derzhavnoi ahrarnoi akademii. 2010. No 7 : Enerhozberezhennya ta alternatyvni dzherela enerhii: problemy i shliakhy yikh vyrishennia. P. $12-17$.

2. Hnap I. V. Influence of nitrogen fertilizers on the growth, productivity and quality of biomass of some varieties of energy willow in the conditions of Western Polissya of Ukraine. Naukovi dopovidi Natsionalnoho universytetu bioresursiv

pryrodokorystuvannia Ukrainy. 2018. No 5. URL:

http://journals.nubip.edu.ua/index.php/Dopovi di/article/view/11664/10113 (last accessed: 04.08.2021).

3. Dospekhov B. A. Methods of field experience (with the basics of statistical processing of research results). 5th ed. Moscow, 1985. 351 p.

4. Economic and energy efficiency of growing bioenergy crops in the western region / M. D. Voloshchuk et al. Peredhirne ta hirske zemlerobstvo i tvarynnytstvo. 2020. Issue 68 (1). P. 35-51.

5. Kravchuk V. On the way to the creation of energy cultures plantations. Tekhnika i tekhnolohii APK. 2013. No 2. P. 31-34.

6. Lys N. M., Fuchylo Ya. D., Tkachuk N. L. Influence of density and application of mineral fertilizers on the growth and productivity of energy willow plantations in the conditions of Prykarpattia. Bioenerhetyka. 2018. No 2 (12). P. 19-21.

7. Makarchenko V. Energetic cultures in Ukraine. Kyiv, 2012. P. 114-117. (Agroexpert: praktychnyi posibnyk ahrariia).

8. Methodology of research of energy plantations of willows and poplars / Ya. D. Fuchylo et al. Kyiv, 2018. 137 p.

9. Roik M. V. Prospects for growing energy willow for biofuel production. Zbirnyk naukovykh prats Instytutu bioenerhetychnykh 
праиьв Інституту біоенергетичних культур і иукрових буряків. 2011. Вип. 12. C. $142-148$.

10. Роїк М. В. Перспективи вирощування енергетичної верби для виробництва твердого біопалива. Біоенергетика. 2013. № 2 . . 18-19.

11. Роїк М. В. Перспективи розвитку біоенергетики в Україні. Цукрові буряки. 2012. № 23. С. 68.

12. Роїк М. В. Роль і місце фітоенергетиків у паливно- енергетичному комплексі України. Цукрові буряки. 2011. № 1. C. 6-7.

13. Ружило 3. Альтернатива природним вуглеводням. Механізація сільського господарства. 2011. № 2. С. 15-18.

14. Савіна С. С. Проблеми i перспективи розвитку виробництва біопалива в Україні. Збірник наукових праць ВНАУ. Серія: Економічні науки. 2011. № 1 (48). С. 166-171.

15. Сінченко В. М., Гнап I. В. Вплив основних елементів живлення на продуктивність енергетичної верби. Біоенергетика. 2018. № 1. С. 9-12.

16. Сінченко В. М., Пиркін В. І., Гнап I. B. Управління технологічними процесами вирощування енергетичної верби. Біоенергетика. 2016. № 2. С. 6-10.

17. Ткачук Н. Л. Вихід енергії та твердого біопалива 3 отриманої біомаси тополі енергетичної залежно від густоти насадження i фону живлення. Аграрна наука та освіта в умовах євроінтеграції : збірник наукових праць Міжнар. наук.практ. конф. (м. Кам'янець-Подільський, 20-21 берез. 2019 р.). Тернопіль : Крок, 2019. Ч. 1. С. 157.

18. Умови, необхідні для вирощування енергетичної верби / Сінченко В. М. та ін. Біоенергетика. 2017. № 2. С. 9-13.

19. Фучило Я. Енергетична верба перспективи вирощування в Україні. Новини агротехніки. 2013. № 1/2. С. 30-31.

20. Фучило Я. Д., Гнап І. В., Ганженко О. М. Ріст і продуктивність деяких сортів енергетичної верби іноземної селекції в kultur i tsukrovykh buriakiv. 2011. Issue 12. P. 142-148.

10. Roik M. V. Prospects for the cultivation of energy willow for the production of solid biofuels. Bioenerhetyka. 2013. No 2. P. 18-19.

11. Roik M. V. Prospects for the development of bioenergy in Ukraine. Tsukrovi buriaky. 2012. No 23. P. 68.

12. Roik M. V. The role and place of phytoenergetics in the fuel and energy complex of Ukraine. Tsukrovi buriaky. 2011. No 1. P. 6-7.

13. Ruzhylo Z. An alternative to natural hydrocarbons. Mekhanizatsiia silskoho hospodarstva. 2011. No 2. P. 15-18.

14. Savina S. S. Problems and prospects for the development of biofuel production in Ukraine. Zbirnyk naukovykh prats VNAU. Seriia: Ekonomichni nauky. 2011. No 1 (48). P. 166-171.

15. Sinchenko V. M., Hnap I. V. The influence of basic nutrients on the productivity of energy willow. Bioenerhetyka. 2018. No 1. P. 9-12.

16. Sinchenko V. M., Pyrkin V. I., Hnap I. V. Management of technological processes of energy willow cultivation. Bioenerhetyka. 2016. No 2. P. 6-10.

17. Tkachuk N. L. Energy yield and solid biofuel from the obtained energy poplar biomass depending on the planting density and feeding background. Ahrarna nauka ta osvita $v$ umovakh yevrointehratsii : zbirnyk naukovykh prats Mizhnar. nauk.-prakt. konf. (m. Kamianets-Podilskyi, 20-21 berez. 2019 r.). Ternopil : Krok, 2019. Part 1. P. 157.

18. Conditions necessary for growing energy willow / Sinchenko V. M. et al. Bioenerhetyka. 2017. No 2. P. 9-13.

19. Fuchylo Ya. Energy willow - the prospect of growing in Ukraine. Novyny ahrotekhniky. 2013. No 1/2. P. 30-31.

20. Fuchylo Ya. D., Hnap I. V., Hanzhenko O. M. Growth and productivity of some varieties of energy willow of foreign selection in the conditions of Volyn Opillya. Plant Varieties Studying and Protection. 2018. Vol. 14, No 2. P. 230-239. DOI: 10.21498/2518-1017.14.2.2018.134775. 
ISSN 0130-8521. Передгірне та гірське землеробство і тваринництво. 2021. Вип. 70 (2)

умовах Волинського Опілля. Plant Varieties Studying and Protection. 2018. T. 14, № 2. C. 230-239. DOI: 10.21498/2518-1017.14.2.2018.134775.

21. Фучило Я. Д., Літвін В. М., Сбитна В. М. Плантаційне вирощування тополі в умовах Київського Полісся. Київ, 2012. 214 c.

22. Фучило Я. Д. Особливості вирощування енергетичної верби. Біоенергетика. 2016. № 1. С. 11-13.

23. Фучило Я. Д. Перспективи вирощування енергетичної верби. Сучасні аграрні технологіï. 2013. № 7. С. 69-71.

24. Фучило Я. Д., Сбитна М. В. Верби України (біологія, екологія, використання). Київ, 2009. 200 с.

25. Хіврич О. Тополя на біопаливо: особливості технології вирощування. Пропозиція. 2016. № 1. С. 66.

26. Чурілов Д. Г. Державне регулювання ринку твердого біопалива як один із чинників збалансованого природокористування. Вісник Полтавськоі державної аграрної академії. 2012. № 2. С. 89-93.

27. Шевчук Р. Біоенергетичні культури для Полісся. Аграрний тиждень Украӥна. 2013. № 31/32. C. 13-14.

28. Шершун М. Х. Еколого-економічні особливості розвитку біоенергетики в зоні Полісся. Економіка АПК. 2012. № 9. С. 19-23.

29. Щербина О. М. Верба енергетична: використання та вирощування. Ужгород, 2011. $104 \mathrm{c}$.

30. Poplar and shrub willow energy crops in the United States: field trial results from the multiyear regional feedstock partnership and yield potential maps based on the PRISM-ELM model / T. A. Volk et al. Global Change Biology Bioenergy. 2018. Vol. 10, Iss. 10. P. 735-751. DOI: 10.1111/gcbb.12498.
21. Fuchylo Ya. D., Litvin V. M., Sbytna V. M. Plantation cultivation of poplars in the conditions of Kivskoho Polissya. Kyiv, 2012. $214 \mathrm{p}$.

22. Fuchylo Ya. D. Features of growing energy willow. Bioenerhetyka. 2016. No 1. P. 11-13.

23. Fuchylo Ya. D. Prospects for growing energy willow. Suchasni ahrarni tekhnolohii. 2013. No 7. P. 69-71.

24. Fuchylo Ya. D., Sbytna M. V. Willows of Ukraine (biology, ecology, use). Kyiv, 2009. 200 p.

25. Khivrych O. Poplars for biofuels: features of cultivation technology. Propozytsiia. 2016. No 1. P. 66.

26. Churilov D. H. The state regulation of market of solid biofuels as one of the factors of balanced nature management. Visnyk Poltavskoi derzhavnoi ahrarnoi akademii. 2012. No 2. P. 89-93.

27. Shevchuk R. Bioenergy crops for Polissya. Ahrarnyi tyzhden Ukraina. 2013. No 31/32. P. 13-14.

28. Shershun M. Kh. Ecological and economic features of bioenergy development in the Polissya area. Ekonomika APK. 2012. No 9. P. 19-23.

29. Shcherbyna O. M. Energy willow: use and cultivation. Uzhhorod, 2011. 104 p.

30. Poplar and shrub willow energy crops in the United States: field trial results from the multiyear regional feedstock partnership and yield potential maps based on the PRISM-ELM model / T. A. Volk et al. Global Change Biology Bioenergy. 2018. Vol. 10, Iss. 10. P. 735-751. DOI: 10.1111/gcbb.12498. 